\title{
J. S. Mill and the formation of the doctrine of the legal regulation of wages
}

\author{
A. M. Lushnikov ${ }^{1}$, M. V. Lushnikova ${ }^{1}$
}

${ }^{1}$ P. G. Demidov Yaroslavl State University, 14 Sovetskaya str., Yaroslavl 150003, Russian Federation

DOI: $10.18255 / 1996-5648-2021-2-202-209$

Research article Full text in Russian

This article is devoted to a whole range of topical problems associated with understanding the legal regulation of wages as one of the main institutions of labor law. In preparing this article, the authors relied on historical, comparative legal and systemic structural methods. The authors linked the genesis of the teaching on wages with the work of the British scientist J.S. Mill. It is reasonably argued that his broad approach, based on a sociological, philosophical, economic and legal analysis of this phenomenon, allowed him to come to very significant conclusions regarding the economic incentives for labor. In the opinion of the authors, the decisive contribution of the British scientist lies in the fact that he separated the "laws" of production from the "laws» of distribution. This opened the way to the possibility of establishing state standards for wages, as well as its legal regulation at three levels: state, social partnership and individual contractual. For the British scientist, the mechanism for fixing wages was a compromise between the interests of workers and employers, taking into account the interests of the state and society. The authors concluded that this approach meets modern realities and is consistent with the important role of collective agreements and local acts in establishing the remuneration system.

Keywords: wages; J. S. Mill; utilitarianism; political economy

\section{INFORMATION ABOUT AUTHORS}

Lushnikov, Andrey M. | E-mail: amlu0909@yandex.ru

Doc. Sc. (Jurisprudence), Doc. Sc. (History), Professor,

Head of the Chair

Lushnikova, Marina V. | E-mail: mvlushnikova@mail.ru

Doc. Sc. (Jurisprudence), Professor, Honored Lawyer

of the Russian Federation

Funding: Yaroslavl State University, Project VIP-014. 


\section{Дж. С. Милль и формирование учения о правовом регулировании заработной платы}

А. М. Лушников ${ }^{1}$, М. В. Лушникова ${ }^{1}$

${ }^{1}$ Ярославский государственный университет им. П. Г. Демидова, ул. Советская, 14 , Ярославль, 150003, Российская Федерация

DOI: $10.18255 / 1996-5648-2021-2-202-209$

Удк 330.8; 349.2

Научная статья

Статья посвящена целому комплексу актуальных проблем, связанных с осмыслением правового регулирования заработной платы как одного из основных институтов трудового права. При подготовке этой статьи авторы опирались на исторический, сравнительно- правовой и системно- структурный методы. Авторы связали генезис учения об оплате труда с творчеством британского ученого Дж. С. Милля. Обоснованно утверждается, что его широкий подход, основанный на социологическом, фрилософрском, экономическом и правовом анализе данного феномена позволил прийти ему к очень значимым выводам касательно экономического стимулирования труда. На взгляд авторов решающий вклад британского ученого заключается в том, что он разделил «законы» производства и «законы» распределения. Это открыло путь к возможности установления государственных стандартов оплаты труда, а также ее правового регулирования на трех уровнях: государственном, социально-партнерском и индивидуально-договорном. Для британского ученого механизм установления заработной платы представлял собой достижение компромисса между интересами работников и работодателей с учетом интересов государства и общества. Авторами сделан вывод, что такой подход отвечает современным реалиям и согласуется с важной ролью коллективных договоров и локальных актов в установлении системы оплаты труда.

Ключевые слова: заработная плата; Дж. С. Милль; утилитаризм; политическая экономия

\section{ИНФОРМАЦИЯ ОБ АВТОРАХ}

Лушников, Андрей Михайлович

Доктор юридических наук, доктор исторических наук, профессор, заведующий кафедрой

Лушникова, Марина Владимировна $\mid$ E-mail: mvlushnikova@mail.ru

Доктор юридических наук, профессор,

Заслуженный юрист РФ

Финансирование: ЯрГУ, проект VIP-014. 
Лушников А. М., Лушникова М. В.

Институт заработной платы имеет наиболее тесное взаимодействие с экономикой, причем это касается не только определения размера фонда оплаты труда, но и видов заработной платы, ее структуры, схем стимулирования творческого отношения к труду и др. В этой связи совсем не случайно этот комплекс проблем активно изучали ученые-экономисты. Одним из них являлся англичанин Дж. С. Милль (1806-1873), который более известен как фрилософ-утилитарист и социолог. Именно его разносторонний подход и позволил рассмотреть заработную плату в более широком социальном контексте. В данном аспекте нас интересует прежде всего его главное экономическое исследование «Основания политической экономии с некоторыми из их приложений к общественной философии» (1848), часто сокращаемое как «Основы политической экономии» [1]. Эта работа неоднократно переиздавалась, в том числе в советский период [2].

Начнем с констатации очевидного: без рассмотрения фрилософрских, социологических, а отчасти и правовых воззрений невозможно понять взгляды Дж. С. Милля на экономику и на «стыковые» проблемы заработной платы. Один из примеров именно такого подхода дает работа итальянца А. Ронкалья, где различные ипостаси Милля-исследователя даны в органическом сочетании [3, с. 281-293]. В конце концов, Дж. С. Милль является не только автором нового прочтения утилитаризма, но и ключевой фигурой сначала «рилософского радикализма», затем одним из первых идеологов социального либерализма, теоретиком феминизма и даже демократии в ее современном прочтении как власти большинства (собственно, власти народа), но с учетом и при защите интересов меньшинства. Его можно считать сторонником расширения влияния государства на общественные процессы, но исключительно посредством права и правоприменения. Неслучайно выдающийся британский экономист Дж. М. Кейнс связал именно с «временем Джона Стюарта Милля» отказ от почти религиозной веры в стихийную упорядоченность экономических отношений при рыночной экономике без всякого вмешательства государства, усиление симпатий к социализму [4, с. 268].

Нам же интересно прежде всего то, что является действительно революционным в его учении о заработной плате и на что экономисты неоклассического направления обычно вообще не обращают внимание. На наш взгляд, главной заслугой в данном аспекте стало разделение «законов» производства и «законов» распределения. На это обычно в позитивном контексте обращают внимание только экономисты-кейнсианцы, причем с расставлением различных акцентов. Напротив, австриец Ф. А. Хайек ожидаемо заявил в беседе с британцем Л. Роббинсом, что считает такое разделение губительным. Впрочем, последний, даже будучи последовательным либералом, вступился за соотечественника [5, с. 301].

Дж. С. Милль смело утверждал, что человеческое общество может использовать произведенные блага по своему усмотрению. Он писал, что «распределение богатства зависит от законов и обычаев общества. 
Дж. С. Милль и фрормирование учения о правовом регулировании...

Правила, которые определяют распределение богатства, таковы, какими их делает мнение и желания правящего части общества и весьма различны в разных странах и в разные эпохи...". В этой связи "общество может подчинять распределение богатства любым правилам, какие оно считает наилучшими; но какие практические результаты проистекают из действия этих правил - это должно быть открыто, подобно любым другим фризическим или отвлеченным истинам, посредством наблюдения или исследования» [2, т. 1, с. 137-139].

Такой вывод принципиально не соответствует позиции как последователей Д. Рикардо, так и современных сторонников экономического детерминизма (в духе «экономического империализма»), утверждающих, что экономика определяет всё и против «законов» распределения идти бесполезно.

Напротив, для Дж. С. Милля не были «естественными» и «экономически обоснованными» ни нищета большинства рабочих, ни то, что заработная плата распределялась обратно пропорционально трудовому вкладу (кучка собственников получала почти все, а рабочие - прожиточный минимум). Если это действительно "естественно», то общество посредством реформирования законодательства может изменить такую ситуацию. Это может быть осуществлено через целый комплекс мер, в том числе через установление императивного минимума заработной платы, определение ее соотношения с культурными запросами и прожиточным минимумом и др.

При этом не стоит отрицать, что производство и распределение связаны между собой и распределять в больших масштабах непроизведенное - верх абсурда (или, по меньшей мере, неумеренное раздувание дефицита бюджета). Однако Дж. С. Милль открыл путь не к волюнтаризму, а окно возможностей, пространство для маневра, вариативность действий в рамках имеющихся ресурсов и действующей правовой системы. Можно сказать, что британец доказал возможность реформирования капитализма на его собственных принципах (с сохранением частной собственности, используемой в производственной деятельности, свободы предпринимательства, рыночной экономики). Он утверждал, что при сложившейся ситуации главной целью «является не ниспровержение системы частной собственности, но ее улучшение и перераспределение такого полного права каждому члену общества участвовать в приносимых ею выгодах» [2, т. 1, c. 360,361$]$.

Дж. С. Милль разделял труд на производительный и непроизводительный с учетом вклада, вносимого этими видами труда в экономическую общественную активность. Он признавал сложность такого разграничения, однако считал его обоснованным именно в контексте заработной платы, так как именно производительный труд создает чистую добавленную стоимость, а не производительный связан уже с перераспределением. $\mathfrak{K}$ непроизводительному труду он относил труд госслужащих, военных, врачей, учителей, музыкантов, танцоров, домашней прислуги. Однако любой труд он считал 
Лушников А. М., Лушникова М. В.

полезным и достойным адекватного вознаграждения, но для экономического роста более важным считал производительный труд. Это явно устаревшая позиция, однако заслуга нашего героя заключается в том, что в число видов производительного труда он включил труд, способствующий производительному (труд по обучению трудовым навыкам, труд госслужащих, обеспечивающих организацию производства, охрану собственности и др.).

Подход британца к проблемам заработной платы вытекал из его общих мировоззренческих установок, а он был гуманист и сторонник прогресса, защитник равноправного сотрудничества людей, свободы и терпимости как абсолютных ценностей. В этой связи даже такой проницательный исследователь, как голландский экономист M. Блауг, несколько упрощенно трактует его предложение законодательно регулировать продолжительность рабочего дня рабочих. Для Дж. С. Милля продолжительное свободное (внерабочее) время было именно «общественным благом», а не голым, но далеко идущим расчетом на то, что в перспективе уменьшение рабочего времени может привести к увеличению индивидуальной выработки. Такая изрядная экономизация правового и нравственного подхода современным ученым [6, с.198-199] не представляется нам обоснованной. Акцентируем внимание на том, что предложение уменьшить рабочее время сопровождалось требованием не уменьшать заработную плату.

Сам Дж. С. Милль последствия сокращения рабочего времени связывал с тем, что у рабочих «будет столько же возможностей для всякого рода умственной культуры, морального и общественного прогресса, сколько будет места совершенствованию Искусства жизни». При всем уважении к труду британец считал его средством обеспечения достойной жизни, а не сводил к нему всю жизнь. В частности, он писал, что «труд ... не хорош сам по себе. Нет ничего похвального в труде ради самого труда...Ценность труда, безусловно, не в том, чтобы оно приводило к еще большему количеству труда и так далее, до бесконечности... В противовес “евангелию труда" я бы предложил евангелие безделья и считал бы, что человеческие существа не могут достичь высших свойств своей природы посредством жизни, заполненной трудом». При этом «по справедливости, каждый человек обязан выполнить свою долю труда и у общества есть неоспоримое право заявлять каждому, что если он не выполнит эту долю, то не будет и есть. Общество пока не реализовало это право, временно отложив вопрос о справедливости ради других дел» [7, с. 56-58]. Таким образом, продолжительность рабочего времени для него представляет проблему справедливости, а не экономической целесообразности. При этом в любом случае заработная плата должна обеспечивать одобряемый обществом стандарт жизненного уровня.

С этим же связано его внимание к обязательному образованию детей, как первичному условию их подготовки к взрослой профессиональной деятельности и карьерному росту. Свободное время для рабочих он считал за- 
Дж. С. Милль и фрормирование учения о правовом регулировании...

логом их дальнейшего образовательного и культурного роста, последующей полноценной и органичной жизни [2, т. 3, с. 367 и др.]. В свою очередь, более высокий уровень образования открывал путь для более квалифицированной работы, а та способствовала культурному росту. Это была своеобразная игра «на повышение», но по выбору самого работника.

Стоит отметить, что Дж. С. Милль отверг разработанную британским экономистом Д. Рикардо «доктрину фронда заработной платы (рабочего фонда)», согласно которой зарплата рабочих не может увеличиваться, так как некий закон природы ограничивает их долю внутреннего национального продукта размером фризического выживания. Выглядело это примерно так: объективно сорормированный «фонд заработной платы» (который в принципе не мог быть увеличен, но связан с ростом инвестиций в предшествующий выплате зарплаты период и зависит от технических условий производства) делился на число работников в соответствии с их прожиточным минимумом, обеспечивающим физическое выживание. Следовательно, размер зарплаты определялся только численностью работников (в связи с чем и стоит снижать рождаемость), тогда как «фонд» фрормировался объективно, хотя имеет при этом тенденцию к повышению по мере роста экономики. Отсюда очевидный вывод: бесполезно требовать повышения заработной платы через профсоюзы, в индивидуально-договорном порядке или устанавливать ее минимум в законе. В этом заключался «козырной» аргумент работодателей всех времен и народов при отказе увеличить зарплату.

Это был печально известный «железный закон заработной платы», названный так позднее Ф. Лассалем (1825-1864). Еще в «Основах политической экономии» британец постепенно отходил от вышеназванной “доктрины фонда заработной платы», в частности допуская давление профсоюзов на ее повышение или увеличение фонда заработной платы за счет уменьшения трат на роскошь собственников капитала. Действительно, до настоящего времени, и особенно в России, ведущий аргумент против повышения заработной платы состоит в том, что это уменьшит инвестиции в производство, будет препятствовать найму новых работников, уменьшит затраты на научные исследования и др. Вероятно, в российских реалиях это скорее помешает очередному «эффективному менеджеру» или «звезде приватизации» 90-х гг. прошлого века купить новую виллу на Лазурном Берегу во Франции, очередную квартиру в Лондоне либо поместить на офшорный счет сумму со многими нулями в иностранной валюте.

В 1869 г. Дж. С. Милль окончательно отказался от «доктрины фронда заработной платы» в пользу того, что ее размер, в том числе минимальный, определяется не только экономическими фракторами, но и расстановкой классовых сил, переговорной силой работодателей и профсоюзов, наконец, законодательным порядком. Это открыло путь усилению роли профсоюзов в распределении доходов предприятий и в конечном итоге к правовому регулированию заработной платы как одному из ключевых институтов тру- 
Лушников А. М., Лушникова М. В.

дового права. Отсюда и вывод о том, что профсоюзы - не помеха рынку труда, а необходимый элемент такого рынка.

Британец вплотную подошел к теории циклического развития экономики и теории кризисов, однако его взгляд на положение рабочих при этом был в целом оптимистичным. Даже если чисто экономические фракторы могут ухудшить их материальное состояние, это может сглаживаться интеллектуальным, социальным и нравственным развитием, которые относительно автономны. Даже рост производства он связывал не только с повышением благосостояния, но и с сокращением потребности в занятости, появлением у рабочих времени для интеллектуального развития. Для него прогресс выражался скорее не в непрерывном росте экономики, а в возрастании роли нематериальных ценностей. По его мнению, бедные не должны зависеть от богатых, причем последние должны иметь право выбора своей собственной судьбы. С этим связан отказ от патернализма работодателей в отношении работников. Он не считал достаточным и обеспечение свободы трудовых договоров, ибо работодатели в одностороннем порядке всегда навяжут устраивающие их условия, в том числе относительно заработной платы. Соответственно, работники и работодатели должны взаимодействовать без социального напряжения, в духе солидарности, с учетом представительства интересов работников профрсюзов.

В целом решение "рабочего вопроса» виделось ему на пути достижения компромисса, классового мира и даже, говоря современным языком, социального партнерства. Работодателям не следует смотреть на работников как на «слуг», а работникам на работодателей как «на источник добычи и наживы». Более того, на базе идеи общественной солидарности Дж. С. Милль вплотную подошел к необходимости в случае потери работником заработка выплачивать ему публично установленное пособие по безработице. Так, одно из наиболее цитируемых изречений британца в российской юридической литературе было следующее: «Независимо от всяких метафизических взглядов на сущность нравственности или общественного союза, каждый согласится, что люди должны помогать друг другу... Поэтому пособие, проистекающее из крайней бедности, есть одно из сильнейших прав, какие только могут существовать... [8, с. 6-7]. Естественно, что безработица признавалась одной из главных причин бедности.

При большой разности во взглядах подход к заработной плате Дж. С. Милля имеет некоторое сходство с подходом К. Маркса, хотя бы в части требований об увеличении фронда оплаты труда. При этом, насколько нам известно, ни с работами К. Маркса, ни с самим германским ученым он не был знаком, притом что последний крайне критически относился к Дж. С. Миллю и его социальным и экономическим воззрениям, во многом благодаря компромиссной позиции последнего. Это несколько странно, с учетом того что «Основы политической экономии» Дж. С. Милля и «Манифест Коммуни- 
Дж. С. Милль и фрормирование учения о правовом регулировании...

стической партии» К. Маркса и Ф. Энгельса вышли в один год (1848), а затем авторы многие годы жили в одном городе - Лондоне.

При этом в отношении Милля К. Маркс оговаривался, что его нельзя отнести к «вульгарным экономистам-апологетам [9, с. 624-625]». Немец критиковал своего британского коллегу за эклектизм, за отсутствие строго научной точки зрения, за то, что его «Основы политической экономии» - это «банкротство буржуазной политической экономии», что он создал «компромиссную политическую экономию», призванную согласовать интересы капиталистов с притязаниями работников. Отчасти соглашаясь с этой критикой, отметим, что это скорее не слабая, а сильная сторона его творчества. Эклектика Дж. С. Милля может считаться попыткой синтеза, а половинчатость и склонность к компромиссам - вполне обоснованной позицией с учетом противоположности классовых интересов. Совсем неслучайно социальный либерализм стал основой реформирования трудового и социально-обеспечительного законодательства в начале XX в., причем первоначально в Великобритании и Франции, а затем и в других экономически развитых государствах. Учение Дж. С. Милля о заработной плате также является компромиссным, каковым оно быть и должно. В этой части компромисс между интересами работников и работодателей с учетом интересов общества и государства просто необходим.

\section{Ссылки}

1. Милль Дж. С. Основания политической экономии с некоторыми из их приложений к общественной философрии: в 2 т. СПб.: Изд. А. Н. Пыпина, 1865. Т. 1. 564 с.; T. 2.507 с.

2. Милль Дж. С. Основы политической экономии. М.: Прогресс, 1980. Т. 1. 495 с.; Т. 2.480 с.; 1981. Т. 3.447 с.

3. Ронкалья А. Богатство идей: история экономической мысли. М.: ИД ВШЭ, 2018. 656 c.

4. Кейнс Дж. M. Конец Laissez-faire // Истоки. М.: Высшая школа экономики, 1998. Вып. 3. С. 260-279.

5. Роббинс Л. История экономической мысли. М.: Изд.-во Ин-та Гайдара, 2017. 488 c.

6. Блауг М. Экономическая мысль в ретроспективе. М.: Дело ЛТД, 1994. 720 с.

7. Милль Дж. С. Негритянский вопрос. Письмо редактору «Журнала Фрейзера», написанное в ответ на «Речь по поводу негритянского вопроса» Карлейля в «Журнале Фрейзера для города и деревни» за январь 1850 г. // Истоки: Экономика - «мрачная наука»? М.: ИД ВШЭ, 2019. С. 50-64

8. Дерюжинский В. Ф. Заметки об общественном призрении. М.: Кн. маг «Гросман и Кнебель», 1897. 115 с.

9. Маркс К. Капитал. Т. 1 // Маркс К., Энгельс Ф. Собр. соч. Т. 23. 907 с. 